Case Report

\section{Acrometastasis as first sign of adenocarcinoma of the lung}

\author{
Zuhat URAKÇ|1*, Senar EBINNÇ ${ }^{1}$, Mehmet KÜÇÜKÖNER ${ }^{1}$, Suat \\ MORKUZU ${ }^{2}$, Özge YAMAN COŞKUN ${ }^{1}$, Zeynep ORUÇ ${ }^{1}$, Yasin \\ SEZGiN'1, Erkan BíLEN', Oğur KARHAN', Nadiye AKDENiZ', \\ Muhammet Ali KAPLAN' ${ }^{1}$ and Abdurrahman IŞIKDOĞAN' ${ }^{1}$
}

'Department of Medical Oncology, Dicle University, Medical Faculty, Diyarbakır, Turkey

${ }^{2}$ Lice Halis Toprak Vakfi State Hospital, Diyarbakır, Turkey

\section{Abstract}

Lung cancer is a major cause of morbidity and mortality worldwide. Metastasis can be seen in many organs in advanced-stage disease. Acral metastasis rate in cancer is quite low. However, because of the direct opening of the arterial circulation, the risk of acral metastasis stem from lung cancer is higher than any other cancers. Although the mechanism is not known exactly, acral metastases occur in dominant extremities. Here, we present a case with lung adenocarcinoma metastasis of the left hand in the second phalanx. We presented this case which is rarely seen in the literature to emphasize acral metastases.

\section{Introduction}

Lung cancer effect 1.8 million people worldwide each year and cause around 1.6 million people dead [1]. In The United State of America lung cancer effect 230.000 people and cause death of more than 140.000 people each year [2]. The symptoms and evidence of lung cancer might be caused by the local and distance metastases or seconder to the paraneoplastic syndrome. The most common symptoms are cough, dyspnea, chest pain, and weight loss [3]. Cough is the main reason for pysician visit around 50\% - 75\% of cases and mostly found in central airway squamous cell carcinoma and small cell lung cancer. Otherwise hemoptysis is present in $20 \%-50 \%$ of patients in their first hospital visit $[4,5]$. Bone metastasis due to malignancies usually occur to the red marrow rich bones and rarely metastasis to the acral bones [6]. Almost half of the acral metastases that have reported in the literature are from lung cancer. Following lung cancers the most common acral metastasis are coming from kidney and breast cancers. Acral metastases are seen in the age range of 18-91 years, with a mean age of 58 years. Overall the most common location of metastases is the right hand and third finger [7-10].

\section{Case Report}

Sixty three years old male patient applied hospital because of swollen wound on his second finger of the left hand, which

\section{More Information}

*Address for Correspondence: Zuhat URAKÇI, Dicle University, Medical Faculty, Oncology Hospital, Medical Oncology Clinic, Sur, Diyarbakır, Turkey, Tel: (0535) 69488 14; Email: dr.zurak@hotmail.com

Submitted: 11 February 2020

Approved: 21 February 2020

Published: 26 February 2020

How to cite this article: URAKÇI Z, EBINÇ S, KÜÇÜKÖNER M, MORKUZU S, YAMAN COŞKUN $\mathrm{OY}$, et al. Acrometastasis as first sign of adenocarcinoma of the lung. Arch Case Rep. 2020; 4: 007-009.

DOI: 10.29328/journal.acr.1001029

ORCiD: orcid.org/0000-0003-3878-988X

Copyright: @ 2020 URAKÇI Z, et al. This is an open access article distributed under the Creative Commons Attribution License, which permits unrestricted use, distribution, and reproduction in any medium, provided the original work is properly cited.

Keywords: Lung cancer; Adenocarcinoma; Acrometastasis

Check for updates

OPEN ACCESS

has started around 4 months ago caused by workplace injury. After the result of biopsy from tissue on his finger showed malignancy, the patient referred to Diyarbakır Dicle University Medical Oncology Department. Physical examination showed rales on his lung sounds, an infectious ulceration which $4 \mathrm{X} 4$ $\mathrm{cm}$ on distal of the second finger of left hand (Figure 1). After a diagnostic test, $5 \mathrm{~cm}$ mass on his right lung middle zone was found and positron emission tomography (PET-CT) showed primary mass and bone metastasis (Figure 2). The biopsy of his lung mass was reported as a hepatoid adenocarcinoma (Figure 3). The patient was accepted as stage IV lung adenocarcinoma.

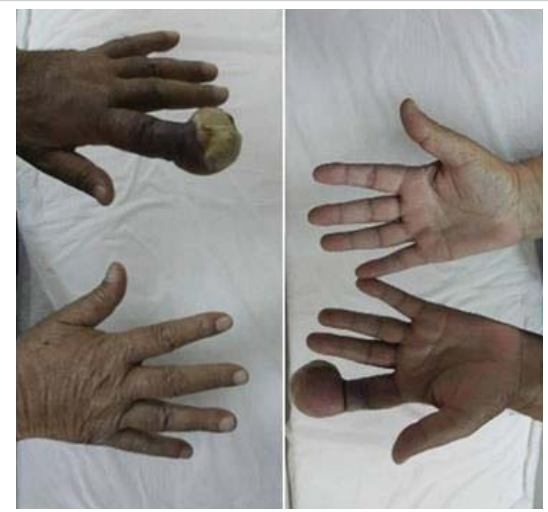

Figure 1: An ulcerated mass is seen in the distal part of the second finger of left hand. 


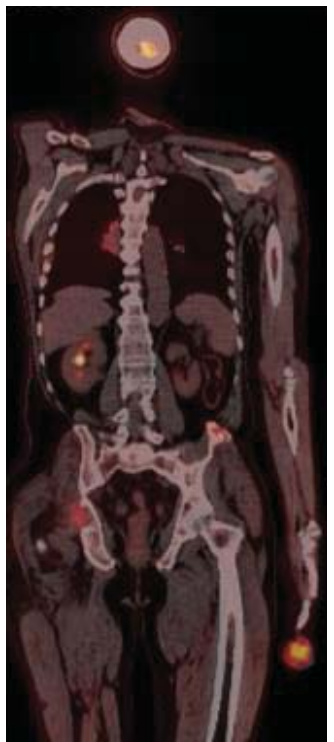

Figure 2: Tumor structure showing FDG uptake is seen in the right lung hiler region and second finger of left hand.

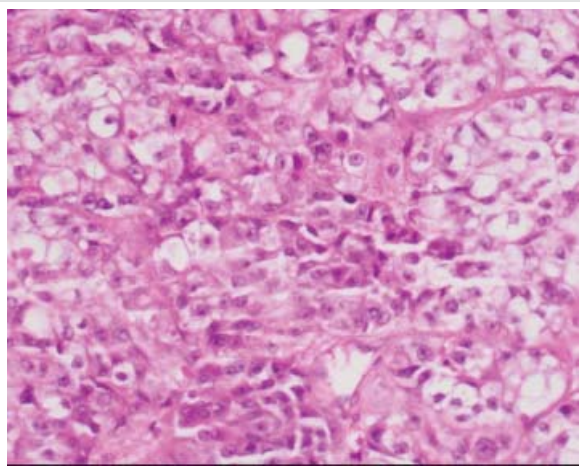

Figure 3: Tumoral structure consisting of cells with wide eosinophilic cytoplasm, vesicular nuclei and prominent nucleoli (H\&E400x).

EGFR, ALK, ROS1 mutations in biopsy material were negative which were looked for targeted therapies. Gemcitabine 1000 $\mathrm{mg} / \mathrm{m}^{2}$ (day 1 and 8 ) and cisplatin $75 \mathrm{mg} / \mathrm{m}^{2}$ (day 1) were started every 21 days. Amputation had done on his second finger of the left hand with metastatic mass. For the metastasis of pelvic bone radiotherapy and zolendronik acid $4 \mathrm{mg} / \mathrm{month}$ started. Patient had partial response after 3 treatments cycles. The patient treatment is still continued and being followed up in our clinic.

\section{Discussion}

Lung cancers may present with metastases in various locations of the body. The main metastasis areas of lung cancers are liver, adrenal glands, brain and skeletal system. Liver metastases should come in mind when liver enzymes level elevated or can be detected in torax computed tomography (CT) screening insidentally [11]. PET-CT can detect adrenal metastasis as well as other sites [12]. Tumor size and lymph node involvement can predict brain metastases [13], while hypercalcemia and alkaline phosphatase may suggest bone metastases [14]. Hypercalcaemia may also be a sign of a paraneoplastic syndrome [15].
As in this case, hand acrometastasis is very rare in cancer patients and accounts for approximately $0.1 \%$ of all bone metastases [16]. Hand metastasis was first described in 1906 in a case of breast cancer presenting with multiple metastases to metacarpal bones [17]. However $47 \%$ of acral metastases occurring in the hand are caused by lung cancer [18]. Hand metastases of lung cancer are mainly in male patients with smoking history. Therefore, it suggests that acral metastases may be related to smoking. Interestingly, acral metastases are two times more common in dominant hand, this may be due to more blood supply and susceptible to trauma of dominant hand [19]. Thus, it is logic that the trauma predisposes tissue more vulnerable so tumor cells can settle and grow in the skeletal system easily[20].

In human body, there are some barriers act to prevent direct access of tumor cells to the arterial system, such as the liver and lung but lung cancer does not have this natural barrier [21]. Fifty per cent of acral metastases are originated from lung via hematogenous and arterial system support this idea [18]. Pattern of acral metastasis of cancers are different too, bronchial carcinomas usually produce a single and lytic lesion whereas breast carcinoma tend to be multiple sclerotic lesions [22].

On the other hand, there are some clues that give an idea about the mechanism of acral metastasis. For example; leukocytosis and thrombocytosis may also occur in the course of lung cancer $[23,24]$ and thrombocytosis is associated with short survival [25]. Another paraneoplastic process, hypertrophic osteoarthropathy (HPO); can result from the condition of lung cancer, cystic fibrosis and lung infections HPO mechanism is not fully understood. At same time, in connection with the situations it has been suggested that some growth factors, such as platelet-derived growth factors, may bypass the lung via megakaryocytes and release of growth factors in the distal extremities may be clinically related $[26,27]$. Neovascularization is also thought to play a role in tumor-induced vascular endothelial growth factors that induce edema and bone growth $[28,29]$. We estimate that these processes in lung cancer contribute to acral metastasis from platelet-derived growth factor and other growth factors.

Patients with acrometastasis have a worse prognosis, in one case report patient with acral metastasis has 6-months survival [30]. Although worse prognosis lead doctors to palliative treatment, the localization of the primary disease and extention of the disease should be major factor of treatment decisions. Amputation, curettage, wide excision, chemotherapy and radiotherapy are modalities can be used alone or in combination in treatment [31,32]. In our case; we administered chemotherapy for control of systemic disease, radiotherapy and bisphosphonate for bone metastases in addition to performed finger amputation. Currently, our case is still being treated as a stable disease.

As conclusion; although acral metastasis is rarely seen in 
oncology practice, most of these cases originated from lung cancer. Especially in patients presenting with non-healing wound and mass should alert orthopedics, plastic surgery and family physicians about an occult lung cancer.

\section{References}

1. Brambilla E, Travis WD. Lung cancer. In: World Cancer Report, Stewart BW, Wild CP (Eds), World Health Organization, Lyon 2014.

2. Siegel RL, Miller KD, Jemal A. Cancer statistics, 2019. CA Cancer J Clin. 2019; 69: 7-34.

PubMed: https://www.ncbi.nlm.nih.gov/pubmed/30620402

3. Kocher F, Hilbe W, Seeber A, Pircher A4, Schmid T, et al. Longitudinal analysis of 2293 NSCLC patients: a comprehensive study from the TYROL registry. Lung Cancer. 2015; 87: 193-200.

PubMed: https://www.ncbi.nlm.nih.gov/pubmed/25564398

4. Hyde L, Hyde Cl. Clinical manifestations of lung cancer. Chest. 1974; 65: 299-306

PubMed: https://www.ncbi.nlm.nih.gov/pubmed/4813837

5. Chute CG, Greenberg ER, Baron J, Korson R, Baker J, et al. Presenting conditions of 1539 population-based lung cancer patients by cell type and stage in New Hampshire and Vermont. Cancer. 1985; 56: 2107-2111. PubMed: https://www.ncbi.nlm.nih.gov/pubmed/2992757

6. Kerin R. The hand in metastatic disease. J Hand Surg Am. 1987; 12: 77-83. PubMed: https://www.ncbi.nlm.nih.gov/pubmed/3543107

7. Tolo ET, Cooney WP, Wenger DE. Renal cell carcinoma with metastases to the triquetrum: case report. J Hand Surg Am. 2002; 27: 876-881. PubMed: https://www.ncbi.nlm.nih.gov/pubmed/12239679

8. Kerin R. Metastatic tumors of the hand. J Bone Joint Surg Am. 1958; 40-A: 263-277.

PubMed: https://www.ncbi.nlm.nih.gov/pubmed/13539054

9. Guttmann G, Stein I. Metastatic tumor of the thumb from adenocarcinoma of the colon. Int Surg. 1968; 49: 217-221. PubMed: https://www.ncbi.nlm.nih.gov/pubmed/5672886

10. Gallagher B, Yousef G, Bishop L. Subungual metastasis from a rectal primary: case report and review of the literature. Dermatol Surg. 2006; 32: 592-595.

PubMed: https://www.ncbi.nlm.nih.gov/pubmed/16681673

11. Hillers TK, Sauve MD, Guyatt GH. Analysis of published studies on the detection of extrathoracic metastases in patients presumed to have operable non-small cell lung cancer. Thorax. 1994; 49: 14-19.

PubMed: https://www.ncbi.nlm.nih.gov/pubmed/8153934

12. Oliver TW Jr, Bernardino ME, Miller JI, Mansour K, Greene D, et al. Isolated adrenal masses in nonsmall-cell bronchogenic carcinoma. Radiology. 1984; 153: 217218.

PubMed: https://www.ncbi.nlm.nih.gov/pubmed/6473783

13. Mujoomdar A1, Austin JH, Malhotra R, Powell CA, Pearson GD, et al Clinical predictors of metastatic disease to the brain from non-small cell lung carcinoma: primary tumor size, cell type, and lymph node metastases. Radiology. 2007; 242: 882-888.

PubMed: https://www.ncbi.nlm.nih.gov/pubmed/17229875

14. De Wever W, Vankan Y, Stroobants S, Verschakelen J. Detection of extrapulmonary lesions with integrated PET/CT in the staging of lung cancer. Eur Respir J. 2007; 29: 995-1002.

PubMed: https://www.ncbi.nlm.nih.gov/pubmed/17331966

15. Hiraki A, Ueoka H, Takata I, Gemba K, Bessho A, et al. Hypercalcemialeukocytosis syndrome associated with lung cancer. Lung Cancer. 2004; 43: 301-307.

PubMed: https://www.ncbi.nlm.nih.gov/pubmed/15165088
16. Kerin R. Metastatic tumors of the hand. A review of the literature. $J$ Bone Joint Surg Am. 1983; 65: 1331-1335.

PubMed: https://www.ncbi.nlm.nih.gov/pubmed/6654944

17. Handley WS. Cancer of the Breast and its Operative Treatment. London: John Murray; 1906.

18. Asencio G, Hafdi C, Pujol H, Allieu Y. Osseous metastases in the hand A general review of three cases. Ann Chir Main. 1982; 1: 137-145. PubMed: https://www.ncbi.nlm.nih.gov/pubmed/6927376

19. Healey JH, Turnbull AD, Miedema B, Lane JM. Acrometastases. A study of twenty-nine patients with osseous involvement of the hands and feet. J Bone Joint Surg Am. 1986; 68: 743-746. PubMed: https://www.ncbi.nlm.nih.gov/pubmed/3459730

20. Joll CA. Metastatic tumors of bone. Br J Surg. 1923; 11: 38-72.

21. Amadio PC, Lombardi RM. Metastatic tumors of the hand. J Hand Surg Am. 1987; 12: 311-316.

PubMed: https://www.ncbi.nlm.nih.gov/pubmed/3559096

22. Libson E, Bloom RA, Husband JE, Stoker DJ. Metastatic tumours of bones of the hand and foot. A comparative review and report of 43 additional cases. Skeletal Radiol. 1987; 16: 387-392.

PubMed: https://www.ncbi.nlm.nih.gov/pubmed/3306939

23. Kasuga I1, Makino S, Kiyokawa H, Katoh H, Ebihara $Y$, et al. Tumorrelated leukocytosis is linked with poor prognosis in patients with lung carcinoma. Cancer. 2001; 92: 2399-2405.

PubMed: https://www.ncbi.nlm.nih.gov/pubmed/11745296

24. Hamilton W, Peters TJ, Round A, Sharp D. What are the clinical features of lung cancer before the diagnosis is made? A population based casecontrol study. Thorax. 2005; 60: 1059-1065.

PubMed: https://www.ncbi.nlm.nih.gov/pmc/articles/PMC1747254/

25. Aoe K1, Hiraki A, Ueoka H, Kiura K, Tabata M, et al. Thrombocytosis as a useful prognostic indicator in patients with lung cancer. Respiration. 2004; 71: 170-173.

PubMed: https://www.ncbi.nlm.nih.gov/pubmed/15031573

26. Dickinson CJ. The aetiology of clubbing and hypertrophic osteoarthropathy. Eur J Clin Invest. 1993; 23: 330-338.

PubMed: https://www.ncbi.nlm.nih.gov/pubmed/8344332

27. Pedersen NT. Occurrence of megakaryocytes in various vessels and their retention in the pulmonary capillaries in man. Scand J Haematol. 1978; 21: 369-375.

PubMed: https://www.ncbi.nlm.nih.gov/pubmed/734350

28. Abe $Y$, Kurita $S$, Ohkubo $Y$, Usui $H$, Hashizume $T$, et al. A case of pulmonary adenocarcinoma associated with hypertrophic osteoarthropathy due to vascular endothelial growth factor. Anticancer Res. 2002; 22: 3485-3488. PubMed: https://www.ncbi.nlm.nih.gov/pubmed/12552943

29. Olán F, Portela M, Navarro C, Gaxiola M, Silveira LH, et al. Circulating vascular endothelial growth factor concentrations in a case of pulmonary hypertrophic osteoarthropathy. Correlation with disease activity. J Rheumatol. 2004; 31: 614-616.

PubMed: https://www.ncbi.nlm.nih.gov/pubmed/14994415

30. Shannon FJ, Antonescu CR, Athanasian EA. Metastatic thymic carcinoma in a digit: a case report. J Hand Surg Am. 2000; 25: 1169-1172. PubMed: https://www.ncbi.nlm.nih.gov/pubmed/11119681

31. Ozcanli H, Ozdemir H, Ozenci AM, Söyüncü $Y$, Aydin AT. Metastatic tumors of the hand in three cases. Acta Orthop Traumatol Turc. 2005; 39: 445-448.

PubMed: https://www.ncbi.nlm.nih.gov/pubmed/16531705

32. Ioia JV, Sumner JM, Gallagher T. Presentation of malignancy by metastasis to the carpal navicular bone. Clin Orthop Relat Res. 1984: 230-233.

PubMed: https://www.ncbi.nlm.nih.gov/pubmed/6467720 